\title{
Foreign direct investment in the storm of the COVID-19 pandemic and the example of Visegrad countries
}

\author{
KÁLMÁN KALOTAY ${ }^{1 * *}$ (i) and MAGDOLNA SASS ${ }^{2 *}$ \\ ${ }^{1}$ United Nations Conference on Trade and Development, Geneva, Switzerland (retired) \\ ${ }^{2}$ Institute of World Economics, Centre for Economic and Regional Studies, Tóth Kálmán u. 4, Budapest, \\ H-1097, Hungary
}

Received: June 30, 2021 • Revised manuscript received: July 26, 2021 - Accepted: August 15, 2021

(C) 2021 The Author(s)

\begin{abstract}
The immediate effects of COVID-19 on the global flows of foreign direct investment (FDI) were devastating, resulting in a large drop. Flows to the Visegrad countries were also affected but less than the world average. The fall in FDI was the result of underlying trends that started before the pandemic but accentuated by the latter, creating a "perfect storm". These secular trends include the digitalisation of production and the birth of Industry 4.0, resulting in more asset-light international production and reorganisations of company networks, the sustainability imperative, making the impact of FDI more relevant than its quantity, and a slowdown in the liberalisation of the policy framework for FDI both in individual countries and at the multilateral level. The recovery of FDI from the shock of 2020 is expected to be long and it will be impossible to return to the pre-pandemic structural and geographical patterns. Building resilience and diversification of production at the expense of the search for the lowest-cost locations will be the top priorities of investors, forcing the host countries to revise their investment promotion strategies focused on cost reduction. In the Visegrad countries, the model based on low labour costs will sooner or later reach its limits.
\end{abstract}

\section{KEYWORDS}

foreign direct investment, crisis, pandemic, Visegrad countries

\footnotetext{
${ }^{*}$ Corresponding author. E-mail: sass.magdolna@krtk.hu

** The views are those of the author and do not necessarily reflect the opinion of the United Nations.
} 


\section{JEL CLASSIFICATION INDICES}

F21, F23, L52, 025, 052

\section{INTRODUCTION}

FDI is one of the best known and most researched phenomena of the contemporary world economy. Together with international trade, it is a glue that holds together international production and the global value chains (GVCs). Due to the fact that the bulk of international trade is directly or indirectly controlled by multinational enterprises (MNEs), the trade and foreign direct investment (FDI) are intimately interlinked between each other. Due to this situation, developments in the two have major implications for prosperity in the world economy, for job creation, for the transfer of technology and many other benefits of the international economy with deep implications for wellbeing in both host and home economies.

The long-term historical evolution of FDI has been far from being linear. One of the low points was the protectionist era between the two World Wars and the period of destruction during World War II (1929-1945). The post-War period saw some resurgence in FDI, especially related to the needs of reconstruction, but the phenomenon remained relatively constrained under the conditions of the Cold War and decolonialisation. A real boom of FDI was observed in the quarter of century following the fall of the communist system in 1989-1990.

World FDI stock grew tenfold in the period of 1991-2015, twice as fast as international trade and three times faster than global GDP (Kalotay 2020). This fast expansion, coupled by a geographical expansion, made FDI an important engine of GDP growth. However, it was also noted that an important part of the FDI flows became delinked from international production. The growing phenomenon of "indirect FDI" (Kalotay 2012) led to the financialisation of FDI, which inevitably touched a ceiling in the Global Financial Crisis of 2007-2008. As the growth of the financial component was more constrained, the growth of FDI in the post-crisis recovery remained slower than growth in the pre-crisis boom. In parallel, new "brakes" to the fast growth of FDI emerged. These factors, such as the digitalisation of the world economy, the emergence of Industry 4.0, the sustainability imperative and the weakening of the open multilateral trading system as well as the rise of more protectionist and nationalist tendencies, will be analysed in the subsequent section of this article.

In this pre-2020 context, many pre-conditions were ready for a "perfect storm" for FDI, ${ }^{1}$ with potentially very negative effects (UNCTAD 2020). Nevertheless, a crisis coming from a pandemic, instead of the economy proper, especially the often-criticised financial sector, took the whole world by surprise. First of all because this was really the first global pandemic since the so-called Spanish flue in 1918. The contemporary world has experienced various epidemics and pandemics (HIV/AIDS, SARS, Ebola and Zika) but these episodes did not halt the machinery of global production. Nor did they require draconian lockdowns leading to the suspension of work in various branches of the economy. From a hindsight, it would have been evident to foresee

\footnotetext{
${ }^{1}$ Originally, the term "perfect storm" denoted a meteorological event aggravated by a rare combination of circumstances.
} In analogy, it is applied to an unusually severe crisis caused by the interaction of various - mostly unfavourable - trends. 
why such an outbreak would devastate FDI, dependent on the well-oiled movement of goods, services and sometimes people. However, even when the first news arrived from Wuhan in December 2019 on the identification of a new virus, nobody thought of modifying the forecasts for a moderate growth in FDI. Then events accelerated, and by March 2020, it had become evident that COVID-19 had changed the conditions for FDI irrevocably.

This article examines the impact of COVID on the flows of FDI in the world economy, and specifically, in the Visegrad countries. We rely on the existing literature and statistical data. After indicating some data problems and a short review of the literature in which we compare the impacts of various crises on FDI, we document the fall in FDI during the first year of the pandemic and the main factors behind it. After listing the policy challenges in this new situation, we turn to describing the developments in the Visegrad countries. The last section concludes.

\section{A CAVEAT - DATA PROBLEMS}

Our article relies mainly on publicly available FDI data. Nevertheless, one must note that these data can be increasingly considered as an imperfect proxy for direct capital flows and productive capacities. As it was already mentioned, for example, the "financialisation" of FDI and an increased reliance on indirect FDI resulted in a weaker link between "real" FDI and data recorded as FDI.

FDI statistics, published by the central banks connected to the balance of payments (b.o.p.), are in principle the main sources of information on inward and outward direct investment flows and stocks. International organisations also base their data on these national statistics. However, the purpose of the b.o.p. is to record the various financial transactions between the country in question and the rest of the world. Thus, FDI data collected from b.o.p. do not necessarily correspond fully to the direct investment concept of economic analysis (Antalóczy - Sass 2015) and, as it was mentioned, there are an increasing number of transactions recorded as FDI, which do not fully comply with the operational definition of FDI. International organisations update their definitions and recommendations for data collection from time to time in order to reflect changes in realities in the world economy, but of course, there is always a time gap and there are always unresolved questions and differences in data collection and correction methods among countries (such as for example using surveys or estimations, full sample or representative samples and various valuation methods for their FDI stocks) resulting in data problems. Crisis years are especially prone to such data problems, as in these periods multinational companies increasingly use transactions aimed at loss reduction and tax optimisation (UNCTAD 2011). The rising frequency of the activities of multinationals in terms of tax optimisation (Lipsey 2007; Contractor 2016) as well as the increased inclination of large multinationals to set up affiliates in tax havens with that purpose (Jones - Temouri 2016) are shown by numerous authors. The more and more frequent use of tax havens and the developed countries offering beneficial tax regulations inflates FDI flow data more and more often (Damgaard et al. 2019). Furthermore, there are also detailed references to transactions, which should be recorded as FDI, while there is no new direct capital involved, such as company reorganisations (UNCTAD 2016). This caveat should be made before we delve deeper into the analysis of the developments in FDI flows in the world economy. 


\section{LEARNING FROM THE LESSONS OF PREVIOUS CRISES: MAIN POINTS OF THE LITERATURE}

When the pandemic is in a relatively initial stage, the analysis of its impact is often based on hypotheses. These hypotheses will be confirmed or rejected in the coming years. Even so, we can derive lessons from the past crises, naturally with taking into consideration the unique nature of the COVID crisis, namely its origins in a medical event, making it very different from the previous, mostly finance-induced external shock. Yet, not learning from the previous crises would also be a mistake for various reasons. Having noted the dissimilarities, there is still a strong rationale for analysing and comparing at least the major crises affecting a large part of the world economy. These crises have certain elements of commonality such as the disruption of operations for MNEs making business as usual impossible for many of them. There is an immediate pressure to react and to adjust the operations. All of a sudden, activities may be forced to shrink, and some firms may go out of business.

But MNEs are also forced to re-experience the value of resilience, at least for some time, before the recovery makes them forget a part of it. That may be in turn one of the reasons why the subsequent crises continue to be severe. The nature of resilience however changes from crisis to crisis. It may be mistaken to go for a resilience that responds to the lessons of the previous and not the future crisis, the same way as generals of a loser army try to reform their war strategy to the needs of the lost war, instead of preparing for the needs of the next one. It should not be lost of sight either that a crisis always opens business opportunities for either well prepared or lucky MNEs, such as the digital giants or certain health industry firms which benefited largely from the pandemic-related conjuncture. How it happens gives us particularly valuable insights both for "economic history" and the understanding of the future behaviour of firms. Finally, going beyond the dissimilarities of crises, there are general lessons to be learned for the understanding of the behaviour of the main protagonists: governments, corporations and society.

The points below synthesise the key findings of selected studies on key issues related to the FDI-crisis nexus:

- In past crises, FDI was usually found more stable and more resilient than other financial flows (especially portfolio investment) due to its link with productive capacities, and the inherent fixed and sunk costs. ${ }^{2}$ In turn, it has been highlighted that FDI was affected more than macroeconomic phenomena such as GDP or trade. ${ }^{3}$

- There is no consensus yet about which of the crises has had the biggest and the most lasting impact on FDI. In general, evidence has shown that the Global Financial Crisis, by its financial nature was the deepest and the longest crisis so far ${ }^{4}$. Nevertheless, the COVID crisis, with its unique nature could also become the longest and deepest recession (OECD 2020). Studies also show that there is no clear indication if FDI returns to its pre-crisis level. In the case of the

\footnotetext{
${ }^{2}$ For the Asian crisis, see Thompson - Poon (2000); Athukorala (2003); Doraisami (2007), and for the Global Financial Crisis, see Vintila (2011); Lund et al. (2018).

${ }^{3}$ For the Asian crisis, see Doraisami (2007); Thangavelu et al. (2009), and for the Global Financial Crisis, see Lund et al. (2018).

${ }^{4}$ Calderon - Didier (2009); Poulsen - Hufbauer (2011); Vintila (2011).
} 
Asian crisis, some show FDI recovery ${ }^{5}$ whereas others show declining FDI inflows into the South-East Asian region in the post-crises period despite output growth (Thangavelu et al. 2009).

- Each crisis bought about sectoral changes in FDI. There was a shift towards more exportoriented activities in the Asian crisis ${ }^{6}$ and in Eastern Europe towards higher value-added activities and non-financial services after the Global Financial Crisis (Kalotay 2016). There are also country-level studies in the COVID crisis (e.g., Khutko 2020 for Russia) that found structural changes in favour of agri-food, machinery, pharma and logistics. The vulnerability of FDI in the less developed regions has not been tested many times. There is at least an evidence on that for Sub-Saharan Africa (Brambila-Macias - Massa 2010).

- Cross-border mergers and acquisitions (MঊAs) seem to fall less than other forms of international flows as they are essential components of corporate restructurings and because of "fire sales". Yet, it is unclear how big fire sales were and if their impact was always negative ${ }^{7}$ or positive $^{8}$. It has been highlighted that in the Asian crisis, some of the M\&A transactions that were thought to be fire sales were in fact takeovers that saved acquired firms and protected their activities (Zhan - Ozawa 2001).

- Some studies have also found that MNEs adjusted to the crisis relatively fast, and that their production and financial linkages could also benefit the local partner firms (Alfaro - Chen 2010). The trajectory of FDI in crisis may also depend on the motivation of investment. For example, in the Asian crisis, it was efficiency seeking investment that led recovery (Edgington - Hayter 2001). Some studies asserted that FDI and other types of MNE investment had contributed to stability (Moon et al. 2011) and recovery, others claimed that they were the source of vulnerability (Doraisami 2007). In the same vein, research also shows that FDI facilitated recovery (e.g., Athukorala 2003), while other studies found that it was rather following it. ${ }^{9}$ One study (Simionescu 2016) has found a reciprocal relationship between growth and FDI. It has also been stressed that cross-border M\&As may play an important role in restructuring the economic activities for the post-crisis period (Zhan - Ozawa 2001).

- The analysis of policy reactions has usually been outside the focus of past studies. The mitigating effects of stimulus and recovery programmes has been the focus of some studies (e.g., Teigland et al. 2020). For instance, Thompson - Poon (2000) stressed the need for reforming investment promotion, Plummer - Cheung (2008) focused on the role of investment liberalisation and facilitation (in the aftermath of the Asian crisis), Dornean et al. (2012) the importance of a supporting regulatory environment, and Kalotay (2016) on the need for industrial policy supporting the upgrading of activities.

\section{THE IMMEDIATE CATACLYSM IN FDI}

In 2020, the almost full calendar year of the pandemic, world FDI inflows fell by close to 35\% (Fig. 1), the biggest annual drop since 2001, when the dotcom bubble burst (51\%). The fall

\footnotetext{
${ }^{5}$ Ucal et al. (2010); Hill - Jongwanitch (2009).

${ }^{6}$ Edgington - Hayter (2001); Thangavelu et al. (2009).

${ }^{7}$ Acharya et al. (2007); Poulsen - Hufbauer (2011).

${ }^{8}$ Calderon - Didier (2009); Hill - Jongwanitch (2009).

${ }^{9}$ Thangavelu et al. (2009); Poulsen - Hufbauer (2011).
} 


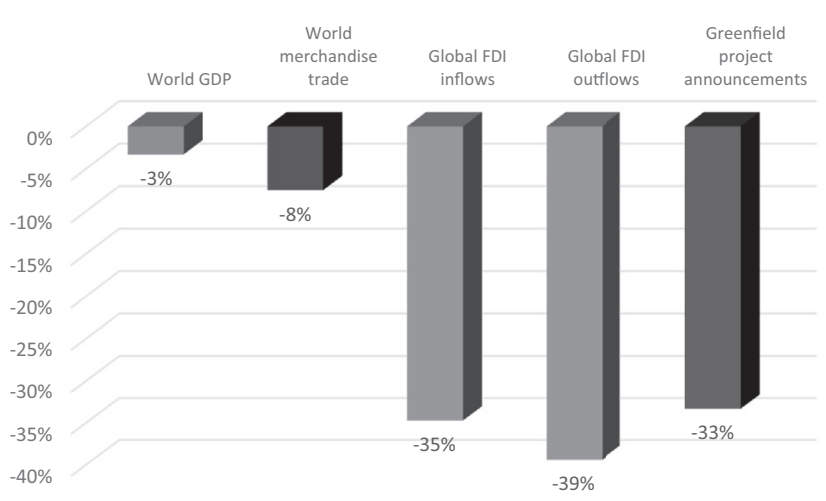

Fig. 1. The impact of the pandemic on selected indicators of the world economy, 2020 (Change over 2019 in percentage)

Source: Authors' calculations, based on UNCTAD data.

registered in outflows was even bigger, more than 39\% (as compared to 55\%) (UNCTAD 2002). It is to be noted however that, in general, data on outflows tend to be less complete, and thus, less reliable than on inflows. In any case, the decline in inward FDI was more than 10 times more than in global GDP and almost 5 times more than in global trade. This is logical as FDI is smaller, and thus, more volatile in crisis. It is also in line with the lessons of past crises described in the previous section. The question is if this crisis turns out to be exceptional in terms of depth (it can be the case) and length (to be confirmed in the future) compared. The drop in the value of greenfield project announcements $(-33 \%$ in 2020 , Fig. 1$)$ indicates that FDI flows are to be expected to be depressed over the upcoming years. Moreover, the de-link with international trade also intrigues observers and raises questions.

There are various possible explanations for sensitivity and lack of resilience in FDI to the effects of the pandemic. They have two common elements: either they emphasise the disproportionately negative effects of the immediate anti-COVID measures, such as lockdowns, stoppages of production and border closures that have affected FDI more than, let us say, local services or production, or they stress the fact that the pandemic accelerated and catalysed the pre-existing trends that would have affected the growth of the volume of FDI negatively even without the crisis. Still, the difference between the decline in international trade and FDI raises questions difficult to answer. If the two are so interlinked according to the theory and the past experience, why the divergence now? Perhaps the answer is this: in the majority of cases, FDI results in the creation of productive assets while trade is typically the one-off transaction. If FDI stops, production still continues with the pre-existing assets but if trade stops, the economy, or large part of it, stops. It remains to be proven if this explanation suffices.

Important to note that FDI was instantly stuck by the lockdown, stoppage and border closing measures in the early weeks of 2020. Some investment expenditures continued (e.g., the fixed running costs of projects), but other outlays were blocked. Announcements of greenfield projects were shelved. Similarly, many M\&As were either suspended or cancelled. Regulators in the 
United States and in Europe reported delays in approval processes for some planned megamergers. ${ }^{10}$ On the policy side, in parallel with temporary trade restrictions taken in some countries to prevent shortages of critical medical supplies during the pandemic, several governments took measures to avoid fire sales of domestic firms during the crisis, introducing new screening requirements and investment restrictions. ${ }^{11}$

In spite of all facts listed above, COVID was not a "gamechanger" for FDI in terms of jumpstarting brand-new trends. It merely accelerated and catalysed three pre-existing trends, namely:

1. Digitalisation and the emergence of Industry 4.0. As a result, the operations of MNEs carrying out FDI had become more intangible and less dependent on the investment in physical assets. Non-equity modes (NEMs) had become established as a governance mechanism for international production (UNCTAD 2011). NEMs allowed MNEs to access markets through contracts, rather than FDI, while still exercising a significant degree of control over operations. Technology-based and digital MNEs also had become increasingly important. These firms can reach markets worldwide through digital channels and without the need for a significant physical presence (UNCTAD 2017). With the pandemic, this trend accelerated (UNCTAD 2021) and the divide between digital and non-digital firms and MNEs increases (Veugelers et al. 2019). Digitalisation may also lead to the reorganisation of global value chains (UNCTAD 2020) with consequences for FDI.

2. The growing imperative for sustainable development. The implementation of sustainability measures in the global operations of MNEs such as climate change adaptation and mitigation, as well as the adoption of rules, regulations and practices aimed at sustainability started well before the COVID crisis, especially with the adoption of the Sustainable Development Goals (SDGs) by the United Nations (UNCTAD 2014). COVID made it clear that the urgency of sustainability from both the point of view of environmental protection (the environmental link of the pandemic) and social development (the need to deal with the social consequences) was immediate and needed to be tackled even at the expense of maximizing FDI flows.

3. The fragmentation of international trade and investment policy making reflecting protectionist and populist pressures, including in the leading market economies such as the United States. In the middle of the pandemic, there was a half-return to multilateralism in the U.S. policies (when President Trump was succeeded by President Biden). Nevertheless, this was too weak and too late to change the course of global policy making, if we evaluate the developments at the time of writing this paper. ${ }^{12}$ These two issues were again not new phenomena prompted by the pandemic. They have been around for some time now, and is referred to as "de-globalisation" or "slowbalisation" or changes in the global integration (Witt 2019) though it may be seen just as a correction to the too intense globalisation before the

\footnotetext{
${ }^{10}$ Such as the acquisition of Deliveroo (United Kingdom) by Amazon (United States) and of Embraer (Brazil) by Boeing (United States).

${ }^{11}$ For example, the European Union issued a guidance concerning investment from non-member economies for the protection of the member States' strategic assets. Australia introduced investment reviews to protect national interest and local assets from acquisition. India introduced control over acquisitions initiated by investors from the neighbouring countries.

${ }^{12}$ First draft was submitted in June 2020.
} 
Global Financial Crisis (Antràs 2020). Views differ whether COVID may accelerate the deglobalisation process mainly through the reorganisation of GVCs (Javorcik 2020) or it will just change the nature and content of flows but will not change the level of globalisation considerably (Williamson 2021).

The interaction of the pandemic with the three long-term trends has been multifaceted. At times, these factors have had mutually reinforcing effects, they occasionally have pushed in opposite directions, and they have played out differently across industries and geographies. In illustration of the divergent trends of productive capacities, this article provides selected examples as measured by the announced greenfield projects and project finance deals in key areas.

The data shown in Fig. 2 are grouped into functions, rather than traditional industries. They show that, unsurprisingly, the conditions of the pandemic accelerated investment in digitalisation (telecom and digital infrastructure) but affected other activities negatively. Only investment in energy (electricity generation and distribution) passed through 2020 with relatively limited decline. Investment related to private sector development (financial and business services) and transportation (connectivity infrastructure) fell more. It also seems that the shift towards Industry 4.0 rather slowed down, as evidenced by the close to $50 \%$ fall in the investment in structural change (industrial upgrading). It also seems that the progress towards the attainment of SDGs via international investment took a big blow as investment in human capital (education, health, water and sanitation) and natural capital (agriculture, natural resources and processing industries) practically collapsed.

Beside differences by industries and corporate functions, there were also major differences among countries and regions as far as the immediate reaction of FDI to the crisis is concerned. In the developed and transition economies, the fall in inflows in 2020 was much bigger than the world average $(-58 \%$ in each), while the developing economies experienced a more limited decline $(-8 \%)$ and developing Asia experienced even a small increase $(+4 \%)$ (Fig. 3). In the United States, the decline was $40 \%$, in Germany $34 \%$ and in the Russian Federation $70 \%$, while in China inflows increased by $6 \%$ and in India 27\% (UNCTAD 2021).

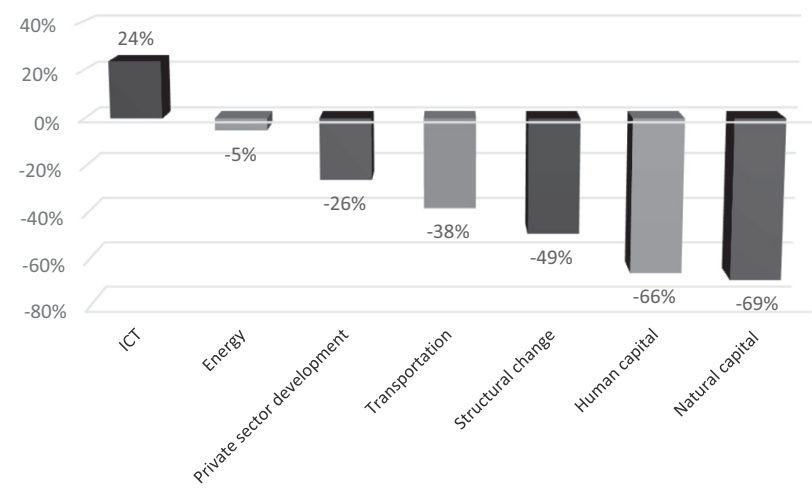

Fig. 2. The impact of the pandemic on selected segments of international investment in productive capacities, 2020 (Change over 2019 in percentage)

Source: The authors, based on UNCTAD (2021). 


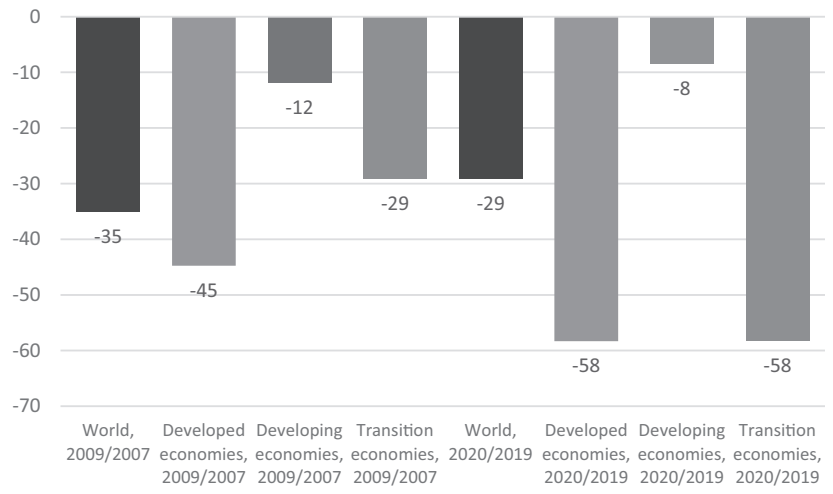

Fig. 3. The decline of FDI inflows by groups of countries, 2009 and 2020 (Change over 2007 and 2019 in percentage)

Source: The authors, based on the UNCTAD, FDI/MNE database. Note: The UNCTAD group of transition economies does not include the new EU member countries, which are listed among the developed economies.

However, we have to be cautious with drawing too far-reaching conclusions from the flows of a single year full of volatility, though it may be tempting to say that the world of FDI became more polarised than ever with the differences between winners and losers becoming larger than ever.

In concluding the analysis of the instant impact, it is important to stress that the decline of inflows in 2020 (35\%) was very similar to the decline of inflows in 2009 compared with the precrisis year of 2007 (33\%). ${ }^{13}$ And, although the economic ramifications of the pandemic have been similarly large for the developed and developing countries alike, as in the Global Financial Crisis, the fall in FDI has been more severe in the developed countries because of the larger size of the financial and M\&A components (UNCTAD 2021: 163).

It is also to be pointed out that, despite the similarities between the two crises in their effect on FDI, there have also been major differences in some respects. Most strikingly, FDI was on an upward trajectory before the Global Financial Crisis, whereas the trend was rather flat before the pandemic. As UNCTAD has noted, "This could make the time it took for FDI to start its recovery after the GFC (about 2.5 years) an unreliable predictor for the start of a substantial recovery in the current context" (UNCTAD 2021: 164). The origin of the two crises was also very different. To the advantage of post-pandemic recovery is the fact that in a health-related crisis, there is more room for expenditure-driven push for the productive sector than in a financial crisis in which expenditures needed to be treated with more caution.

\section{DECLINING CROSS-BORDER INVESTMENTS IN THE IMMEDIATE FUTURE?}

Without surprise, the expectation is that the world of FDI will look very different after the recovery from the world that we knew before the pandemic. There is no consensus however

\footnotetext{
${ }^{13}$ During the Global Financial Crisis, FDI inflows took two years to reach their lowest level.
} 
exactly what the major changes will be, and how fast and robust the recovery will be. Forecasting is particularly challenging in a very volatile environment, where basic economic indicators change by the day. ${ }^{14}$ The most recent modelling by UNCTAD (UNCTAD 2021) predicts a $10 \%$ growth in FDI for 2021, but without taking into consideration any new negative developments in the pandemic such as the appearance of new mutations affecting major economies in the world, or a potential seasonal resurgence of infections in the second half of 2021. The most pessimistic scenario of UNCTAD shows stagnation globally. After the huge decline in 2020, some recovery is expected in the developed countries (but not in the transition economies of the former Soviet Union) and a continued growth in developing Asia but rather flat flows in the rest of the world. Moreover, even if the rate reaches $10 \%$ in 2021 and the rate remains high in the following two years, flows will not recover to their pre-crisis level before 2023.

If the experience of the past crises is used as a predictor, one can hypothesise that the postpandemic recovery indeed could take some time to gather speed. Indeed, an analysis of five global and regional crises before the Global Financial Crisis has found that, when the initial fall in FDI was limited, the recovery was swift, but in the case of more significant FDI declines, the downturn was protracted (Poulsen - Hufbauer 2011).

There is also a general expectation that the patterns of FDI flows will change in the future. The forces behind that include not just digitalisation - that is already very dynamic - but also the need to shift towards more sustainable projects - those projects suffered in the initial phase but may get a big push from investors and from the international community. Moreover, the main consideration of both investors and policy makers will be resilience - mostly resilience to future shocks - and robustness of supply chains. They can become more paramount considerations than cost optimisation. As UNCTAD (2020) has suggested, there is a need to change the "investment-development paradigm" with the following shifts:

1. From a focus on export-oriented efficiency-seeking projects in narrowly specialised production segments to a so-called "export-plus-plus" focus. (The word plus referring to investment in production for regional markets and in a broadened industrial base.)

2. From a focus on cost-based competition for single-location investors to diversified investment based on resilience and flexibility.

3. From prioritising large-scale investors to making room for smaller-scale manufacturing facilities and services.

If these shifts materialise, the pool for investment geared towards exploiting factors of production, resources and low-cost labour will shrink, resulting in a rebalancing of economic growth factors towards the domestic and regional demand and on services. Investment in the green economy and the blue economy, ${ }^{15}$ as well as in infrastructure and domestic services, may also present new potentials for investment.

Changes in FDI flows and global production in the pandemic and post-pandemic world are expected to be multifaceted, and different factors may push FDI to different directions. In

\footnotetext{
${ }^{14}$ The joke that prediction is difficult, especially if it's about the future, commonly attributed to Danish physicist Niels Bohr, is very pertinent here. To be noted that Bohr may have used some old Danish proverb for his adage.

${ }^{15}$ Blue economy refers to the sustainable use of marine resources and environment.
} 
general, four types of trajectories are expected to characterise FDI in the upcoming decade (UNCTAD 2020):

1. Reshoring, which will lead to shorter, less fragmented value chains and a higher geographical concentration of value added, primarily in higher-technology industries. This trajectory may lead to more divestment and a shrinking pool of efficiency-seeking FDI. For some economies, it may give a push to the imperative to re-industrialise, for others to cope with premature deindustrialisation. Access to, and upgrading within, GVCs may become more difficult for developing countries previously specialising on low-cost production (Mihályi - Sass 2019). Reshoring may not affect those activities than rely on the local availability of certain natural resources, especially in "pollutable" environments.

2. Diversification, which will lead to a wider distribution of economic activities. It will primarily affect services and the GVC-intensive manufacturing industries. This trajectory will increase opportunities for new entrants (economies and firms) to participate in GVCs, but reliance on supply chain digitalisation may cause those GVCs to be more loosely governed, platformbased and asset-light, and value capture in the host countries will become more difficult. GVC participation will require high-quality hard and soft (digital) infrastructure.

3. Regionalisation, which will reduce the physical length but not the fragmentation of supply chains. The geographical dispersion of value added will increase. This trajectory will affect regional processing, some GVC-intensive industries and even the primary sector. It will lead to a shift from global efficiency-seeking investment to regional market-seeking investment, and from investment in vertical GVC segments to investment in broader industrial bases and clusters. Regional economic cooperation, industrial policy and investment promotion will become indispensable to benefit from the regional value chains (UNCTAD 2018).

4. Replication, which will lead to shorter value chains and a rebundling of production stages. It will lead to more geographically distributed activities, but also more concentrated value added. This trajectory implies a shift from investment in large-scale industrial activity to distributed manufacturing, which relies on lean physical infrastructure and high-quality digital infrastructure. A local manufacturing base, especially SMEs, and producer services become prerequisites to attract GVCs, but value capture and technology dissemination will not be guaranteed.

It has been suggested (UNCTAD 2020) that reshoring, diversification, regionalisation and replication (i.e., the list above) can overall lead to a declining cross-border investment. Given the importance of FDI for the post-pandemic recovery, for economic growth and job creation, policy makers need to maintain a trade and investment policy environment that favours a gradual adjustment of international production to the new post-recovery world, full of challenges and opportunities. Challenges include increased divestment, relocations and investment diversion, and a shrinking pool of efficiency-seeking investment, implying tougher competition for FDI. Value capture in GVCs and development based on vertical specialisation will become more difficult. Infrastructure built for a world of traditional GVCs will see diminishing returns. Changes in locational determinants of investment will often negatively affect the chances of the developing countries to attract FDI. Opportunities include attracting investors looking to diversify supply bases and building redundancy and resilience. The pool of regional marketseeking investment is also expected to increase. Shorter value chains will bring more investment in distributed manufacturing and final-goods production with broader industrial capacity- 
building and clustering. And digital infrastructure and platforms will enable new applications and services and improve access to GVCs.

\section{FDI IN THE VISEGRAD COUNTRIES}

With the global picture in mind, it is also intriguing to analyse the case of countries and country groups ${ }^{16}$ that have based their development on FDI-intensive strategies and now find themselves at the crossroads of crisis-stricken and post-pandemic FDI. How will these economies respond to these new challenges? Will they seize the opportunities?

For this case study, we have selected the Visegrad countries, and among them Hungary, as they followed a heavily inward-FDI-based development path over the past decades (Nölke Vliegenthart 2009) with different starting times: as for Hungary, the starting point can be dated to around the beginning of the nineties. The other Visegrad countries followed suit later - with Slovakia being the last at around the turn of the millennium. Nevertheless, over time, the impact of the difference in starting times diminished and all four countries became FDI intensive economies. According to UNCTADStat data, these four countries accounted for only $0.8 \%$ of world population and $1.3 \%$ of world GDP in 2019, but $1.5 \%$ global inward FDI stock (and only $0.3 \%$ of global outward FDI stock).

The FDI-intensive strategies of the Visegrad countries were based on a mixture of FDI attraction and domestic economic reforms, helping the transition from centrally planned to market economy, economic modernisation and reintegration in the European and world economy (Mihályi 2001). This strategy has not fulfilled fully the expectations in terms of catching up with Western Europe and showed its vulnerabilities already during the Global Financial Crisis, partly because of a high exposure to the international economy and dependence on GVCs in the demand-sensitive industries (Braun 2020), such as the highly interlinked automotive and electronics industries. Having learned the lessons of this dependence on FDI and exposure to international business cycles and business decisions taken outside their countries, the Visegrad governments reformed, to some extent, the course of their economic policies after the Global Financial Crisis (Sallai - Schnyder 2018). This resulted in a higher level of government intervention in the economies. However, this did not result in a major strategy change, and overall exposure to FDI remained almost the same (Hunya 2017; Sass 2020). Overall, the Visegrad countries still rely mainly on foreign capital in their development path (Bohle - Greskovits 2018; Sass 2021a). Rather, this partly reoriented strategy added to economic priorities some "heavy points" in certain domestic-market-oriented, services activities, under more local ownership using a more intensive and targeted/selective government intervention.

\footnotetext{
${ }^{16}$ The Visegrad Group, Visegrad Four, or V4 is a cultural and political alliance of four countries of Central Europe (Czech Republic, Hungary, Poland and Slovakia), all of which are members of the EU and of NATO, to advance co-operation in military, cultural, economic and energy matters with one another and to further their integration to the EU. The Group traces its origins to the summit meetings of leaders from Czechoslovakia, Hungary and Poland held in the Hungarian castle town of Visegrad on 15 February 1991. Visegrad was chosen as the location for the 1991 meeting as an intentional allusion to the medieval Congress of Visegrad in 1335 between John I of Bohemia, Charles I of Hungary and Casimir III of Poland. For a recent survey of economic developments in the V4 countries, see among others Danska-Borsiak (2018); Sass (2020); Győrffy (2021).
} 




Fig. 4. Inward FDI stock in the Visegrad countries, selected years (Millions of current US dollars) Source: The authors, based on the UNCTAD, FDI/MNE database.

This half-change in strategy was made possible partly because of institutional weaknesses, which were further aggravated by the promotion of local ownership (Bruszt et al. 2020; Györffy 2021).

Due to the lack of a full-fledged strategic alternative, the four countries need a constant inflow of FDI in order to maintain their development path. This seems to be attained up till the Global Financial Crisis, with some backsliding and stagnation afterwards and with a renewed momentum after 2015 (Fig. 4).

The pandemic-related fall in FDI has been affecting the position of the Visegrad countries as well. While they experienced some decline in FDI inflows during 2020, their overall share in global flows, due to the lower rate of decrease compared to other countries, has even improved (Fig. 5) compared to the previous years. ${ }^{17}$

The relatively good performance of the four countries can be connected to the realisation of certain large projects in 2020. Some of these projects are still reflecting the traditional specialisation of these economies in "traditional" efficiency- or market-seeking undertakings, especially in the automotive industry. Nevertheless, quite a number of them are high-technology projects, especially related to the digitalisation wave of the world economy. The number of projects related to sustainable development remained very low. The list of this mix of projects belonging to both the old and the apparent new world includes such flagships as the capacity extension of the Finnish - Swedish Stora Enso (pulp and paper), acquisition of a local firm by the US Facebook or investment by the US data firm Pure Storage in Czechia, ${ }^{18}$ FDI projects by the Chinese energy-material-producing Semcorp, the Korean automotive part producer Doosan or

\footnotetext{
${ }^{17}$ It should be noted that UNCTAD FDI data differ from the b.o.p. data published by the Hungarian National Bank. Furthermore, they differ considerably from the bank's data cleaned from transit capital and asset portfolio restructuring. These "cleaned" data indicate a positive inflow for Hungary in 2016 and on average a plus 300 million Dollar annual inflow between 2016 and 2020. A further remark should be made for the data on Czechia and Poland, containing a relatively high share (well above $10 \%$ in the case of Czechia and just below 10\% for Poland) of roundtripping, i.e., domestic capital returning home after having been invested abroad (Sass 2021b).

${ }^{18}$ See CzechInvest's webpage www.czechinvest.org.
} 


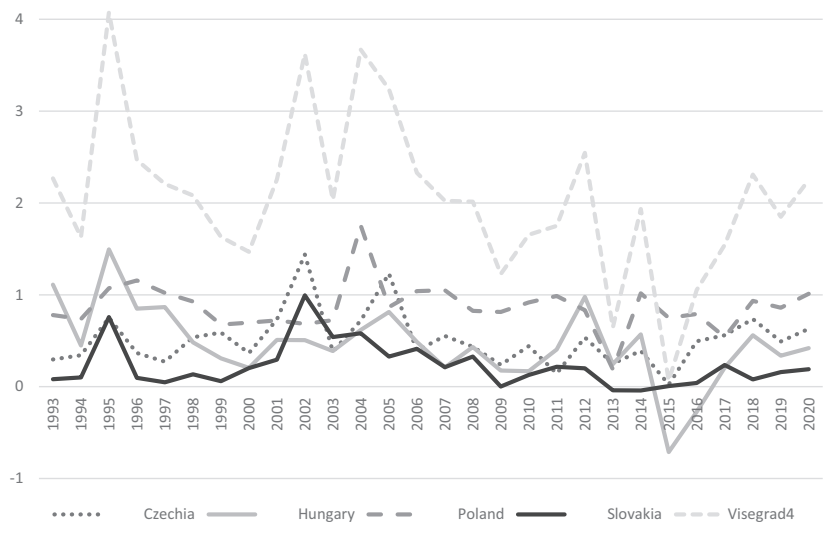

Fig. 5. Share of the Visegrad countries in world FDI inflows, 1993-2020 (\%) Source: Authors' calculation, based on the UNCTAD, FDI/MNE database.

the US software producer Diligent Corporation in Hungary, ${ }^{19}$ the Harvey Nash Technology IT firm from the United Kingdom, the Korean data processing SK Group, the US Alphabet/Google or the Belgian materials technology Umicore Group in Poland, ${ }^{20}$ capacity extension of the German VW Group or new investment by Porsche in Slovakia. ${ }^{21}$

The four countries differed from each other in terms of the most important components of FDI inflows in 2020. According to the preliminary detailed data of the national banks, the main component of FDI in Czechia was rather new FDI (equity), while in Hungary and Poland reinvested earnings and intra-company loans (debt), pointing to different investment promotion strategies in the four countries. But overall, intense investment promotion (and intense competition for FDI) permanently characterises all of them.

In the Visegrad countries, the policy response to the pandemic included not just an intensification of investment promotion either in the form of actively seeking new investors and providing specific generous incentives for FDI in selected (high-technology) industries (e.g., in Czechia) or actively seeking the attention of extra-European investors (e.g., in Hungary). In line with the global trend of protecting of domestic strategic assets against the foreign takeovers at low prices (the so-called fire sales) (UNCTAD 2021), all four Visegrad countries introduced screening mechanisms for the health-related investment. Furthermore, temporary screening mechanisms for foreign takeovers were introduced in Czechia in January 2021, in Hungary until

\footnotetext{
${ }^{19}$ See “A koronavírus járvány ellenére is a sikeres müködőtőke beruházások éve volt 2020" (Despite the coronavirus pandemic, 2020 was a successful year for FDI), Hungarian Investment Promotion Agency, 25 January 2021. https:// hipa.hu/hu_HU/a-koronavirus-jarvany-ellenere-is-a-sikeres-mukodotoke-beruhazasok-eve-volt-2020-.

${ }^{20}$ See the Polish Investment and Trade Agency's webpage: https://www.paih.gov.pl/en.

${ }^{21}$ See Radka Minarechová (2020).
} 
30 June 2021, and in Slovakia in March 2021 based on industry/sector lists, in line with the EU Guidance on FDI screening. Poland required foreign investors from countries outside the European Economic Area to receive prior clearance from the President of the Polish Competition Authority for domestic acquisitions under certain conditions. These measures could have contributed to some extent to the decline of FDI inflows during the first year of the pandemic.

How can the factors, listed in the first part of this article affect FDI inflows in the Visegrad countries, and thus, help them in upgrading their FDI-based development path (perhaps in line with the "flying geese" pattern, emulating the example of the successful Asian region)? There are many question marks and missing statistics, as well as just a short period foregone, which all inhibit a detailed and confident answer to that question. The impact of the digitalisation of production or Industry 4.0 is not easy to forecast either in the world or in the Visegrad countries -as there are contradicting forces at play (UNCTAD 2020). It may have facilitated integration in GVCs for the so-called "factory economies" which specialise in the labour-intensive activities, including in the Visegrad countries (Szalavetz 2020). However, the fate of these economies facing the reconfiguration of production networks may be ambiguous. It may also induce the relocation of labour-intensive activities back into the high-wage developed economies (Inomata - Taglioni 2019), for example, through the intense use of robots (Molnár et al. 2020), with consequences for FDI. There can be various channels, through which Industry 4.0 may modify FDI and the activities of foreign-owned companies (in many cases depending on other changes in the world economy, especially those related to the future of globalisation). For example, FDI inflows can be affected by the reconfigurations of GVCs and production networks, by their geographic diversifications aimed at reaching a higher level of resilience. The absorptive capacities, the structural constraints (in the areas of human capital and infrastructure) and attractiveness of the Visegrad countries may act as important modifying factors (or even barriers) in that respect (Éltető - Sass 2021).

The already mentioned pre-emptive measures to avoid fire sales, if kept in place for a longer period and more permanently, can also shape future FDI to a large extent. Their cooling off effect has sometimes worked in combination with increasing centralisation and decreased manoeuvring room of local authorities in investment promotion. Such centralisation has sometimes led to mismatches between local needs and capacities, and the requirements and expectations of the investors (for the case of a Hungarian countryside town "Tatabánya" see Antalóczy et al. 2021).

It is also an open question how the Visegrad countries will weather the weaknesses of the multilateral trading system during the pandemic and in the recovery phase. The fragmentation of international trade and investment policy making is expected to result in a decreased availability and a higher volatility of FDI, leading to a more intense competition for a shrinking pool of investment, affecting the Visegrad countries negatively. Nevertheless, they may be at least partly protected by the stronger European regional integration, which may increase the importance of the Visegrad countries for extra-EU-investors, seeking both efficiency and larger markets, and thus, producing in the Visegrad countries for the EU market. Signs of that increased attention are already present in the four economies. They may also benefit from the reshoring and regionalisation paths of EU investment responding to the resilience imperative.

Compared with the factors of digitalisation and policy environment, the sustainability issue seems to be less pressing in the Visegrad countries at first sight; at least it does not figure on the top of the "revealed" government priorities. For example, sustainable development is not yet a 
key word in Hungary, except for foreign-owned companies that seem to set the pace for embracing it. $^{22}$

The above facts indicate that the Visegrad countries may have at least partly realised that a new era is dawning on them. However, still there is a rather slow shift from the focus on exportoriented efficiency-seeking projects in the traditional automotive-electronics industries. An encouraging sign within these industries is the rise of e-automotive projects and higher valueadded, service or R\&D undertakings. The vision for international competition for FDI is still mainly cost-based and there are many barriers - especially in terms of the shortage of skilled workforce - to attracting new projects. Though the room for manoeuvre for policy shifts in these relatively small and open economies highly integrated into the EU seems to be limited, change is not impossible within the priorities of FDI attraction at least. For example, centralised investment promotion still focuses on large-scale projects and pays little attention to the local needs and capacities and cannot really handle small-medium projects - which may potentially contribute to a greater extent to sustainable local developments than large projects.

It is also to be emphasised that investment promotion in these countries does not function in isolation from the rest of the economic policies. On the one hand, these promotion efforts are at least part of the national development strategies, which could dictate new priorities. On the other hand, what investment promotion can offer to multinationals depends on the strengths and weaknesses of potential local business partners, including the small and medium-sized enterprises, and the strengths and weaknesses of the local human resources which is tributary to the quality of the education and health systems - in other words, the somewhat neglected sustainability factors. However, having noted the strong and weak points of the Visegrad countries in these areas, those questions already go well beyond the focus of this article - except if governments wish to give a big push to these areas with the help of foreign capital.

\section{CONCLUSIONS}

This article has attempted to analyse the world of FDI in full mutation in the middle of the COVID-19 pandemic. We demonstrated that the pandemic only accelerated and catalysed preexisting trends, which have a significant impact on FDI: digitalisation, the increased importance of sustainability and the fragmentation in international policy-making. To prove the point that everything is in a flux, we have focused on the specific case of the Visegrad countries. As we are living through unprecedented and unparalleled changes, the future is particularly difficult to predict. One conclusion is however certain: there is no way back to the pre-pandemic world. For the Visegrad countries, it means that development strategies based on past patterns of FDI are to be changed. Already in the past, it was thought that the model of assembly operations based on cheap labour would one day reach its limits. Indeed, the logic would dictate that these countries push for industrial upgrading following the "flying geese" pattern. The pandemic adds more stimulus towards that direction. This article has shown that it is already happening in some cases; perhaps not as fast and not as deep as it could or should be.

This period is also a challenge for policy makers. They have to reinvent their investment promotion and facilitation strategies. It is however not clear how fast they have to abandon the

\footnotetext{
${ }^{22}$ See the activities of the Business Council for Sustainable Development in Hungary: https://bcsdh.hu/category/news/.
} 
past strategies and how fast they have to invent new ones. Here naturally we do not refer so much to anti-COVID packages that are more part of firefighting activities than the hallmarks of new types of industrial policies. However, as countries also start announcing recovery packages, the question is to be raised if these packages are designed to move to a new world, or facilitate a return, however improbable, to the pre-crisis situation.

\section{ACKNOWLEDGEMENT}

Magdolna Sass's research was supported by the Hungarian research fund NKFIH (No. 132442).

\section{REFERENCES}

Acharya, V. - Shin, H. S. - Yorulmazer, T. (2007): Fire-Sale FDI. Faculty Research, London Business School. http://facultyresearch.london.edu/docs/Acharya-Shin-Yorulmazer-FDI.pdf.

Alfaro, L. - Chen, M. X. (2012): Surviving the Global Financial Crisis: Foreign Ownership and Establishment Performance. American Economic Journal: Economic Policy, 4(3): 30-55.

Antalóczy, K. - Sass, M. (2015): Through a Glass Darkly: The Content of Statistical Data on Foreign Direct Investment. Studies in International Economics: Special Issue of Külgazdaság, 1(1): 34-61.

Antalóczy, K. - Birizdó, I. - Sass, M. (2021): Regional Investment Promotion to Handle the Consequences of the COVID Pandemic - The Case of Tatabánya. Manuscript, ELKH KRTK Institute of World Economy, Budapest.

Antràs, P. (2020): De-Globalisation? Global Value Chains in the Post-Covid-19 Age. NBER Working Paper, No. 28115.

Athukorala, P. C. (2003): Foreign Direct Investment in Crisis and Recovery: Lessons from the 1997-1998 Asian Crisis. Australian Economic History Review, 43(2): 197-213.

Bohle, D. - Greskovits, B. (2018): Politicising Embedded Neoliberalism: Continuity and Change in Hungary's Development Model. West European Politics, 42: 1069-1093.

Brambila-Macias, J. - Massa, I. (2010): The Global Financial Crisis and Sub-Saharan Africa: The Effects of Slowing Private Capital Inflows on Growth. African Development Review, 22(3): 366-377.

Braun, E. (2020): Kockázatok a magyar gazdaság szerkezetében (Risks of the Hungarian Economic Structure). Külgazdaság, 64(9-10): 62-89.

Bruszt, L. - Lundstedt, L. - Munkacsi, Zs. (2020): Collateral Benefit: The Developmental Effects of EUInduced State Building in Central and Eastern Europe. Review of International Political Economy, 27(5): 1170-1191.

Calderon, C. A. - Didier, T. (2009): Will FDI be Resilient in this Crisis? World Bank Other Operational Studies, 11000, Washington, DC: World Bank. http://hdl.handle.net/10986/11000.

Contractor, F. (2016): Tax Avoidance by Multinational Companies: Methods, Policies, and Ethics. Rutgers Business Review, 1(1): 27-43.

Damgaard, J. - Elkjaer, T. - Johannesen, N. (2019): What Is Real and What Is Not in the Global FDI Network? IMF Working Paper, No. WP/19/274.

Danska-Borsiak, B. (2018): Determinants of Total Factor Productivity in Visegrad Group Nuts-2 Regions. Acta Oeconomica, 68(1): 31-50. 
Doraisami, A. G. (2007): Financial Crisis in Malaysia: Did FDI Flows Contribute to Vulnerability? Journal of International Development: The Journal of the Development Studies Association, 19(7): 949-962.

Dornean, A. - Isan, V. - Oanea, D. C. (2012): The Impact of the Recent Global Crisis on Foreign Direct Investment. Evidence from Central and Eastern European Countries. Procedia Economics and Finance, 3: 1012-1017.

Edgington, D. W. - Hayter, R. (2001): Japanese Direct Foreign Investment and the Asian Financial Crisis. Geoforum, 32(1): 103-120.

Éltető, A. - Sass, M. (2021): A kapitalizmus változatai és az ipar 4.0 a visegrádi országokban (Varieties of Capitalism and Industry 4.0 in the Visegrad Countries). Közgazdasági Szemle, 68(5): 490-514.

Győrffy, D. (2021): Felzárkózási pályák kelet-közép-Európában két válság között (Convergence Paths in Central and Eastern Europe between Two Crises). Közgazdasági Szemle, 68(1): 47-75.

Hill, H. - Jongwanitch, J. (2009): Outward Foreign Direct Investment and the Financial Crisis in Developing East Asia. Asian Development Review, 26(2): 1-25.

Hunya, G. (2017): Conditions for an Investment Revival in Central and Eastern Europe. In: Galgóczi, B. Drahokoupil, J. (eds): Condemned to be Left Behind? Can Central and Eastern Europe Emerge from Its Low-Wage Model? Brussels: European Trade Union Institute (ETUI), pp. 25-46. https://www.etui.org/ Sites/Default/Files/Chapter\%201_6.pdf.

Inomata, S. - Taglioni, D. (2019): Technological Progress, Diffusion, and Opportunities for Developing Countries: Lessons from China. In: Global Value Chain Development Report 2019: Technological Innovation, Supply Chain Trade, and Workers in a Globalized World. Washington, D.C.: World Bank Geneva: World Trade Organization, pp. 83-101. https://doi.org/10.30875/6b9727ab-en.

Javorcik, B. (2020): Global Supply Chains will not be the Same in the Post-COVID-19 World. In: Baldwin, R. E. - Evenett, S. J. (eds): COVID-19 and Trade Policy: Why Turning Inward Won't Work. London: CEPR Press, pp. 111-116. https://voxeu.org/Content/Covid-19-And-Trade-Policy-Why-TurningInward-Won-T-Work.

Jones, C. - Temouri, Y. (2016): The Determinants of Tax Haven FDI. Journal of World Business, 51(2): 237-250.

Kalotay, K. (2012): Indirect FDI. The Journal of World Investment \& Trade, 13(4): 542-555.

Kalotay, K. (2016): Post-Crisis Crossroads for FDI in CEE. In: Szent-Iványi, B. (ed.): Foreign Direct Investment in Central and Eastern Europe: Post-Crisis Perspectives. Cham: Palgrave Macmillan, pp. 23-49.

Kalotay, K. (2020): A Quarter Century of Global Foreign Direct Investment: A Shifting Landscape. In: Spatareanu, M. (ed.): Foreign Direct Investment and the Multinational Enterprise (Vol. 1). Singapore: World Scientific, pp. 11-43.

Khutko, A. (2020): Despite the Covid-19 Pandemic, 99\% of Foreign Direct Investment Projects in Russia will be Implemented. Ernst \& Young. https://www.ey.com/en_ru/news/2020/07/ey-european-attractivenesssurvey-2019.

Lipsey, R. E. (2007): Defining and Measuring the Location of FDI Output. NBER Working Paper, No. 12996.

Lund, S.- Manyika, J. - Mehta, A. - Goldshtein, D. (2018): A Decade after the Global Financial Crisis: What Has (and Hasn't) Changed. McKinsey \& Company Briefing Note, September. https://www. mckinsey.com/Industries/Financial-Services/Our-Insights/A-Decade-After-The-Global-FinancialCrisis-What-Has-And-Hasnt-Changed.

Mihályi, P. (2001): Foreign Direct Investment in Hungary - The Post-Communist Privatisation Story Reconsidered. Acta Oeconomica, 51(1): 107-129. 
Mihályi, P. - Sass, M. (2019): Introduction to the Special Issue on the Internationalisation of Central and Eastern European Firms. Acta Oeconomica, 69(S2): 5-9.

Minarechová, R. (2020): Investors Pursued Projects and Transactions Despite the Virus. The Slovak Spectator, 27 November 2020. https://spectator.sme.sk/C/22538633/2020-Investment-Highlights-FromSlovakia-Investors-Pursued-Projects-Despite-The-Pandemic.Html.

Molnár, E. - Kozma, G. - Mészáros, M. - Kiss, É. (2020): Upgrading and the Geography of the Hungarian Automotive Industry in the Context of the Fourth Industrial Revolution. Hungarian Geographical Bulletin, 69(2): 137-155.

Moon, H. C. - Cheng, J. L. - Kim, M. Y. - Kim, J. U. (2011): FDI, Economic Decline and Recovery: Lessons from the Asian Financial Crisis. Multinational Business Review, 19(2): 120-132.

Nölke, A. - Vliegenthart, A. (2009): Enlarging the Varieties of Capitalism. The Emergence of Dependent Market Economies in East Central Europe. World Politics, 61(4): 670-702.

OECD (2020): Global Outlook on Financing for Sustainable Development 2021. A New Way to Invest for People and Planet. Paris.

Plummer, M. - Cheong, D. (2009): FDI Effects of ASEAN Integration. Région et Développement, 29: 50-67. https://regionetdeveloppement.univ-tln.fr/Wp-Content/Uploads/3-Plummer.Pdf.

Poulsen, L. S. - Hufbauer, G. C. (2011): Foreign Direct Investment in Times of Crisis. Transnational Corporations, 20(1): 19-38.

Sallai, D. - Schnyder, G. (2018): The Transformation of Post-Socialist Capitalism - From Developmental State to Clan State? Greenwich Papers in Political Economy, GPERC57. https://doi.org/10.2139/Ssrn. 3100775.

Sass, M. (2020): Jobb ma egy veréb, mint holnap egy túzok? Alternatív növekedési utak keresése a visegrádi országokban (Is a Sparrow Better Today than a Bustard Tomorrow? Search for Alternative Growth Paths in the Visegrad Countries). ELKH KRTK Institute of World Economics, Working Papers, No. 137, Budapest.

Sass, M. (2021a): FDI-Based Models and What the Future May Have in Store for Them. WiiW Monthly Report 2/2021, pp. 18-26. https://wiiw.ac.at/Monthly-Report-No-2-2021-P-5601.Html.

Sass, M. (2021b): Multinationals from Post-Socialist Countries: How Large Their Foreign Investments Can Be? In: Andreff, W. (ed.): Comparative Economic Studies in Europe: A Thirty-Year Review. Cham: Palgrave Macmillan, pp. 227-248.

Simionescu, M. (2016): The Relation Between Economic Growth and Foreign Direct Investment during the Economic Crisis in the European Union. Proceedings of Rijeka Faculty of Economics - Journal of Economics and Business, 34(1): 187-213.

Szalavetz, A. (2020): Digital Transformation - Enabling Factory Economy Actors' Entrepreneurial Integration in Global Value Chains? Post-Communist Economies, 32(6): 771-792.

Teigland, J. - Lhermitte, M. - Bax, H. (2020): How Can Europe Reset the Investment Agenda Now to Rebuild Its Future? EY Attractiveness Survey, Ernst \& Young. https://www.ey.com/en_ch/attractiveness/ 20/how-can-europe-reset-the-investment-agenda-now-to-rebuild-its-future.

Thangavelu, S. M. - Yong, Y. W. - Chongvilaivan, A. (2009): FDI, Growth and the Asian Financial Crisis: The Experience of Selected Asian Countries. World Economy, 32(10): 1461-1477.

Thompson, E. R. - Poon, J. P. (2000): ASEAN After the Financial Crisis: Links Between Foreign Direct Investment and Regulatory Change. ASEAN Economic Bulletin, 17(1): 1-14.

Ucal, M. - Özgan, K. M. - Bilgin, M. H. - Mungo, J. (2010): Relationship Between Financial Crisis and Foreign Direct Investment in Developing Countries Using Semiparametric Regression Approach. Journal of Business Economics and Management, 11(1): 20-33. 
UNCTAD (2002): World Investment Report 2002: Transnational Corporations and Export Competitiveness. New York and Geneva: United Nations.

UNCTAD (2011): World Investment Report 2011: Non-Equity Modes of International Production and Development. New York and Geneva: United Nations.

UNCTAD (2014): World Investment Report 2014. Investing in the SDGs: An Action Plan. New York and Geneva: United Nations.

UNCTAD (2016): World Investment Report 2016: Investor Nationality: Policy Challenges. New York and Geneva: United Nations.

UNCTAD (2017): World Investment Report 2017: Investment and the Digital Economy. New York and Geneva: United Nations.

UNCTAD (2018): World Investment Report 2018: Investment and New Industrial Policies. New York and Geneva: United Nations.

UNCTAD (2020): World Investment Report 2020: International Production Beyond the Pandemic. New York and Geneva: United Nations.

UNCTAD (2021): World Investment Report 2021: Investing in Sustainable Recovery. New York and Geneva: United Nations.

Veugelers, R. - Rückert, D. - Weiss, Ch. (2019): Bridging the Divide: New Evidence About Firms and Digitalisation. Policy Contribution 17, Bruegel, Brussels, pp. 1-13. https://www.bruegel.org/2019/12/ bridging-the-divide-new-evidence-about-firms-and-digitalisation/.

Vintila, D. M. (2011): Foreign Direct Investments during Financial Crises. Annals of Faculty of Economics, University of Oradea, 1(2): 41-45.

Williamson, P. (2021): De-Globalisation and Decoupling: Post-COVID-19 Myths versus Realities. Management and Organization Review, 17(1): 29-34.

Witt, M. A. (2019): De-Globalization: Theories, Predictions, and Opportunities for International Business Research. Journal of International Business Studies, 50: 1053-1077.

Zhan, J. X. - Ozawa, T. (2001): Business Restructuring in Asia: Cross-Border M\&As in the Crisis Period. Copenhagen: Copenhagen Business School Press.

Open Access. This is an open-access article distributed under the terms of the Creative Commons Attribution 4.0 International License (https://creativecommons.org/licenses/by/4.0/), which permits unrestricted use, distribution, and reproduction in any medium, provided the original author and source are credited, a link to the CC License is provided, and changes - if any - are indicated. (SID_1) 